\title{
Bakteri Coliform dan Non Coliform yang Diisolasi dari Saluran Pernapasan Sapi Bali
}

\author{
(COLIFORM AND NON COLIFORM BACTERIA THAT ISOLATED FROM \\ RESPIRATORY TRACT OF BALI CATTLE)
}

\author{
Putu Putri Wiliantari' ${ }^{1}$ I Nengah Kerta Besung ${ }^{2}$, Ketut Tono PG ${ }^{2}$ \\ ${ }^{1}$ Mahasiswa Program Magister Sains Veteriner Universitas Udayana \\ ${ }^{2}$ Laboratorium Mikrobiologi Veteriner Universitas Udayana \\ Jl. PB. Sudirman Denpasar Bali \\ Email: wiliantariputri@gmail.com
}

\begin{abstract}
ABSTRAK
Penelitian ini bertujuan untuk mengetahui bakteri coliform dan non coliform pada saluran pernapasan sapi bali yang dipelihara di dataran rendah dan dataran tinggi. Sampel diambil pada sapi pedet, dara, dan dewasa sebanyak 36 sampel, kemudian ditumbuhkan pada media Salmonella Shigella Agar dengan metode sebar. Data jumlah koloni coliform dan non coliform dianalisis ragam dan dilanjutkan dengan uji beda nyata terkecil. Hasil penelitian menunjukkan bahwa jumlah bakteri coliform pada sapi bali di dataran tinggi sebanyak 1287,96 Colony Forming Unit/g dan di dataran rendah sebanyak 643,9798 CFU/g dan bakteri non coliform pada dataran tinggi sebanyak 162,2464 $\mathrm{CFU} / \mathrm{g}$ dan di dataran rendah sebanyak $81,12321 \mathrm{CFU} / \mathrm{g}$. Bakteri coliform dan non coliform yang diperoleh di dataran tinggi menunjukkan perbedaan yang tidak nyata dengan bakteri yang diperoleh di dataran rendah.
\end{abstract}

Kata kunci: bakteri coliform; non coliform; dataran rendah; dataran tinggi; sapi bali; umur

\section{ABSTRACT}

The main purpose of this study is to determine the coliform and non coliform bacteria at the respiratory tract of Bali cattle that raised at the lowlands and highlands. 36 Samples were taken on calves, heifers, and adults, then grown on Salmonella Shigella Agar medium by spreading method. Coliform colonies and non coliform colonies were analyzed variably and followed by Least Significant Difference (LSD) test. The results showed that the number of coliform bacteria of bali cattle at the highlands was $1287.96 \mathrm{CFU} / \mathrm{g}$ and at the lowlands was $643.9798 \mathrm{CFU} / \mathrm{g}$ and non coliform bacteria at the highlands was $162.2464 \mathrm{CFU} / \mathrm{g}$ and at the lowlands as much as $81.12321 \mathrm{CFU} / \mathrm{g}$. Coliform and non coliform bacteria were obtained at the highlands and the lowlands showed no significant differences.

Keywords: coliform; non coliform bacteria; highland; lowland; bali cattle; ages

\section{PENDAHULUAN}

Bakteri coliform adalah bakteri batang Gram negatif, yang memfermentasi laktosa, dan bersusun secara tunggal. Bakteri ini menjadi indikator patogen pada hewan dan manusia dikarenakan jumlah koloninya pasti berkorelasi positif dengan keberadaan bakteri patogen. Sedangkan bakteri non coliform adalah golongan bakteri yang tidak mampu memfermentasi laktosa. Contoh bakteri coliform antara lain E. coli, Klebsiella sp., dan Enterobacter sp. Sedangkan bakteri non coliform antara lain Salmonella sp., Proteus sp., dan Shigella sp. Penularan bakteri coliform dan non coliform bisa melalui oral, hidung, udara, dan kontak langsung. Penularan melalui konsumsi air minum yang tidak higienis juga menjadi faktor dalam penularan bakteri coliform dan non coliform (Bambang et al., 2014). Tubuh sapi tidak hanya memerlukan makro dan mikro mineral yang lengkap, tetapi juga memerlukan kandungan mineral dengan jumlah yang cukup untuk pertumbuhannya (Dewantari et al., 2016).

Bakteri coliform dan non coliform yang seharusnya ditemukan di saluran pencernaan ternyata juga ditemukan pada saluran pernapasan. Klebsiella sp. merupakan salah satu bakteri coliform yang 
dapat ditemukan di saluran pernapasan bagian atas. Klebsiella sp. merupakan bakteri flora normal pada saluran pencernaan yang bersifat patogen potensial dan patogen oportunistik yang sangat penting. Bakteri ini menyebabkan infeksi jika berada di saluran pernapasan bagian atas. Infeksi yang ditimbulkan yaitu pada mukosa hidung dan faring, serta menyebabkan pneumonia dan infeksi saluran kencing akibat infeksi yang meluas (Sikarwar, 2011).

Pertumbuhan bakteri coliform dan non coliform dipengaruhi oleh beberapa faktor. Suhu udara pada dataran rendah dan dataran tinggi memiliki pengaruh terhadap jumlah bakteri coliform dan non coliform. Pada dataran rendah suhu harian berkisar antara $25^{\circ} \mathrm{C}$ sampai $32^{\circ} \mathrm{C}$. Sedangkan pada dataran tinggi memiliki suhu harian $15^{\circ} \mathrm{C}$ sampai $25^{\circ} \mathrm{C}$ struktur tanah yang lebih gembur namun memiliki sifat tanah yang lebih baik bila dibandingkan dengan dataran rendah. Selain itu, dataran rendah juga memiliki suhu yang mendekati optimal bagi bakteri sehingga bakteri tumbuh pesat pada dataran rendah (Kadarsih, 2004). Pertumbuhan bakteri akan semakin pesat apabila komponen yang dibutuhkan cukup tersedia (Destriyana et al., 2013).

Umur pada sapi bali juga berpengaruh terhadap jumlah bakteri coliform dan non coliform di dalam tubuh. Hal ini disebabkan karena sistem tanggap kebal pada berbagai tingkat umur juga berbeda. Pada sapi pedet imunitasnya belum terbentuk secara sempurna. Makin dewasa imunitasnya makin terbentuk. Perkembangan umur berakibat meningkatnya kemampuan tubuh terhadap tanggap kebal dan mengeliminasi kuman di dalam tubuh.

\section{METODE PENELITIAN}

\section{Materi Penelitian}

Sampel diambil dengan cara usapan hidung pada sapi bali jantan dan betina, kemudian dimasukkan ke dalam sterile eppendorf yang sudah berisi $\mathrm{NaCl}$ fisiologis dan disimpan di dalam boks yang sudah berisi es batu. Sampel diambil dari lokasi dataran rendah yaitu Kota Denpasar dan Kabupaten Badung dan dataran tinggi yaitu Kabupaten Gianyar dan Kabupaten Bangli. Jumlah sampel yang diambil sebanyak 36 sampel, yang berasal dari sapi pedet, dara, dan dewasa.

\section{Penanaman Sampel}

Sampel sebanyak $1 \mathrm{~g}$ diencerkan sampai pengenceran $10^{-5}$. Setiap pengenceran ditanam sebanyak $0,1 \mathrm{ml}$ pada media Salmonella Shigella Agar (SSA). Koloni diamati setelah diinkubasikan selama 18-24 jam. Koloni yang berwarna merah muda sebagai coliform, dan koloni transparan atau tidak berwarna sebagai non coliform.

Jumlah koloni (N) dihitung dengan rumus:

$N=\frac{1(\text { CFU } / \text { gram })}{\text { Faktor Pengencer } x \text { Vol inokulum }}$

\section{Analisis Data}

Jumlah koloni yang tumbuh pada masing-masing perlakuan dilakukan analisis deskriptif kemudian dilanjutkan dengan analisis varian yang jika hasilnya berbeda nyata dilanjutkan dengan uji BNT.

\section{HASIL DAN PEMBAHASAN}

\section{Hasil}

Hasil penelitian jumlah bakteri coliform dan non coliform pada dataran rendah (Kota Denpasar dan Kabupaten Badung) dan dataran tinggi (Kabupaten Gianyar dan Kabupaten Bangli) berdasarkan umur pada 36 sampel, didapatkan jumlah bakteri yang bervariasi. Rataan jumlah bakteri coliform dan non coliform usapan hidung sapi bali terlihat pada table 1.

Berdasarkan Tabel 1. dapat diketahui rataan hasil penelitian jumlah bakteri coliform pada sapi bali di dataran rendah sebanyak 36.15 $\pm 70.49 \mathrm{CFU} / \mathrm{g}$ dan dataran tinggi sebanyak $35.39 \pm 64.37 \quad \mathrm{CFU} / \mathrm{g}$. Sedangkan rataan jumlah bakteri non coliform yang ditemukan pada dataran rendah sebanyak $5.86 \pm 11.85 \mathrm{CFU} / \mathrm{g}$ dan rataan jumlah yang ditemukan di dataran tinggi $3.15 \pm 10.37 \mathrm{CFU} / \mathrm{g}$. Data hasil tersebut menunjukkan bahwa jumlah 
bakteri coliform dan non coliform di dataran rendah lebih tinggi bila dibandingkan dengan dataran tinggi. Pada berbagai tingkat umur berdasarkan tabel di atas dapat diketahui bahwa rataan jumlah bakteri coliform di dataran rendah pada sapi pedet sebanyak $48.30 \pm 116.60 \mathrm{CFU} / \mathrm{g}$, dara sebanyak $44.65 \pm 34.75 \mathrm{CFU} / \mathrm{g}$, dan dewasa sebanyak $15.50 \pm 36.20 \mathrm{CFU} / \mathrm{g}$. Sedangkan bakteri non coliform di dataran rendah pada pedet sebanyak $11.02 \pm 16.00 \mathrm{CFU} / \mathrm{g}$, dara sebanyak $0.70 \pm 0 \quad \mathrm{CFU} / \mathrm{g}$ dan dewasa sebanyak 5.90 $\pm 12.65 \mathrm{CFU} / \mathrm{g}$. Di dataran

Tabel 1. Rataan Jumlah Bakteri Coliform dan Non Coliform pada Sapi Bali di Dataran Rendah dan Dataran Tinggi pada Berbagai Tingkat Umur.

\begin{tabular}{lcc}
\hline & Dataran Rendah (CFU/g) & Dataran Tinggi (CFU/g) \\
\hline Coliform & $48.30 \pm 116.60$ & $69.00 \pm 100.45$ \\
S1 & $44.65 \pm 34.75$ & $5.90 \pm 12.65$ \\
S2 & $15.50 \pm 36.20$ & $31.35 \pm 37.70$ \\
S3 & $36.15 \pm 70,49$ & $35.39 \pm 64.37$ \\
Rataan \pm SD & & \\
Non Coliform & $11.02 \pm 16.00$ & $8.04 \pm 18.00$ \\
S1 & $0.70 \pm 0$ & $0.70 \pm 0$ \\
S2 & $5.90 \pm 12.65$ & $0.70 \pm 0$ \\
S3 & $5.86 \pm 11.85$ & $3.15 \pm 10.37$ \\
Rataan \pm SD &
\end{tabular}

Keterangan: S1= Sapi Pedet, S2= Sapi Dara, S3= Sapi Dewasa

\section{Pembahasan}

Analisis statistik menunjukkan bahwa daerah pemeliharaan sapi bali yaitu di dataran tinggi maupun di dataran rendah tidak berpengaruh nyata $(\mathrm{P}>0,05)$ terhadap log bakteri coliform dan non coliform. Umur sapi yaitu pedet, dara, dan dewasa tidak berpengaruh nyata $(\mathrm{P}>0,05)$ terhadap log bakteri coliform dan non coliform. Umur pada dataran tidak berpengaruh nyata $(\mathrm{P}>0,05)$ terhadap log bakteri coliform dan non coliform.

Ditemukannya bakteri coliform dan non coliform pada saluran pernapasan sapi bali bisa terjadi dikarenakan pada saat makan maupun minum, terjadi reflek lidah sapi yang menjilat rongga hidung sehingga terjadi cemaran bakteri enterobactericeae yang berada pada saluran pencernaan dapat tumbuh pada saluran pernapasan sapi. tinggi jumlah bakteri coliform pada sapi pedet sebanyak $69.00 \pm 100.45 \mathrm{CFU} / \mathrm{g}$, dara sebanyak 5.90 $\pm 12.65 \mathrm{CFU} / \mathrm{g}$, dan dewasa sebanyak 31.35 $\pm 37.70 \mathrm{CFU} / \mathrm{g}$. Sedangkan baketri non coliform di dataran tinggi pada sapi pedet sebanyak $8.04 \pm 18.00 \mathrm{CFU} / \mathrm{g}$, dara sebanyak $0.70 \pm 0 \mathrm{CFU} / \mathrm{g}$, dan dewasa sebanyak $0.70 \pm 0 \mathrm{CFU} / \mathrm{g}$. Dari hasil data tersebut menunjukkan bahwa bakteri coliform dan non coliform yang ditemukan di dataran rendah dan dataran tinggi pada sapi pedet lebih tinggi bila dibandingkan dengan sapi dara dan dewasa. 
(lingkungan dan cemaran pakan) dan faktor dalam (sistem kekebalan tubuh). Faktorfaktor lingkungan yang mempengaruhi pertumbuhan bakteri yaitu suhu, $\mathrm{pH}$, dan oksigen. Suhu memiliki pengaruh yang sangat penting terhadap fase adaptasi pertumbuhan bakteri. Ketika suhu mendekati suhu minimum, tidak hanya mengurangi kecepatan pertumbuhan tetapi juga memperpanjang fase adaptasi (Kadarsih, 2004). Hal ini sangat penting dalam proses penyimpanan makanan pada suhu dingin. Jika makanan disimpan di bawah suhu minimum, maka bakteri akan tumbuh lambat (Ray, 2001). Pernyataan tersebut sejalan dengan penelitian ini dimana jumlah bakteri coliform dan non coliform lebih banyak ditemukan pada dataran rendah bila dibandingkan dengan dataran tinggi dimana suhu harian di dataran rendah yaitu $25^{\circ} \mathrm{C}-32^{\circ} \mathrm{C}$ mendekati suhu optimum pertumbuhan bakteri, selain itu dataran rendah juga memiliki lahan yang kritis sehingga berpengaruh terhadap air minum maupun pakan yang dikonsumsi oleh ternak sapi, dimana air sangat mudah terkontaminasi bakteri coliform (Suarjana, 2009). Bakteri coliform dan non coliform yang sering ditemukan pada saluran pernapasan adalah bakteri yang biasanya berada di saluran pencernaan atau golongan enterobactericeae. Bakteri tersebut antara lain Escherichia, Salmonella, Shigella, Klebsiella, Enterobacter, dan Proteus (Koneman and Procop, 2006).

Selain faktor lingkungan, faktor cemaran pada pakan juga mempengaruhi jumlah bakteri pada sapi bali. Menurut Bambang et al. (2014) semakin tingginya tingkat pencemaran air dan pakan pada sapi bali, maka semakin tinggi pula risiko adanya bakteri pada sapi bali itu sendiri. Hal ini dikarenakan air minum di dataran rendah kurang higienis dan tercemar bakteri coliform. Namun pada dataran tinggi juga berpengaruh terhadap kemurnian air minum dikarenakan air minum yang didapatkan langsung dari sumber mata air (Bambang et al., 2014). Hasil yang didapatkan tidak berbeda nyata dikarenakan pada saat pengambilan sampel terjadi peralihan musim dari musim panas ke musim penghujan (Besung et al., 2016).

Berdasarkan hasil penelitian dimana pada sapi pedet yang dipelihara di dataran rendah maupun dataran tinggi, didapat rataan jumlah bakteri coliform dan non coliform lebih tinggi bila dibandingkan dengan sapi dara dan dewasa. Hal ini disebabkan karena antibodi pada sapi pedet belum terbentuk secara sempurna, berbeda pada sapi dewasa dimana antibodi pada sapi dewasa sudah terbentuk secara sempurna akibat paparan agen infeksi secara berulang.

Pendapat di atas sejalan dengan Riko et al. (2012), dimana faktor dalam yaitu kekebalan tubuh (imunitas) juga mempengaruhi pertumbuhan bakteri pada sapi bali. Sistem imun pada hewan terbagi menjadi dua yaitu imunitas bawaan dan imunitas adaptif. Imunitas bawaan didapat dari induk, bersifat non-spesifik dan merupakan pertahanan pertama dalam melawan infeksi. Imunitas bawaan pada hewan muda belum cukup untuk menghadapi agen asing yang ada di lingkungan karena belum terbentuk secara sempurna dan hanya berasal dari induknya. Sedangkan imunitas adaptif pada hewan dewasa merupakan bagian penting dari sistem kekebalan tubuh hewan yang mengatur tubuh dalam merespon agen infeksi atau antigen, imunitas adaptif akan semakin membaik akibat infeksi yang berulang.

\section{SIMPULAN DAN SARAN}

\section{Simpulan}

Jumlah bakteri coliform dan non coliform pada saluran pernapasan sapi bali di dataran rendah tidak berpengaruh nyata bila dibandingkan dengan yang dataran tinggi. Jumlah bakteri coliform dan non coliform pada saluran pernapasan sapi bali pada sapi pedet tidak berpengaruh nyata bila dibandingkan dengan dara dan dewasa.

\section{Saran}


Perlu dilakukan penelitian lebih lanjut mengenai identifikasi jenis-jenis bakteri coliform dan non coliform yang lebih spesifik yang berada di saluran pernapasan sapi bali di dataran tinggi dan dataran rendah pada berbagai umur.

\section{UCAPAN TERIMAKASIH}

Penulis mengucapkan terimakasih yang sebesar besarnya kepada: Rektor Universitas Udayana, Ketua Lembaga Penelitian dan Pengabdian kepada Masyarakat Universitas Udayana, dan Dekan Fakultas Kedokteran Hewan Universitas Udayana atas dana Hibah Unggulan Program Studi (HUPS) tahun 2015 serta fasilitas dan kesempatan yang diberikan. Penulis juga mengucapkan terimakasih kepada Dosen Pembimbing dan kepada semua pihak yang telah membantu penelitian ini.

\section{DAFTAR PUSTAKA}

Bambang AG, Fatimawali, Kojong NS. 2014. Analisis Cemaran Bakteri Coliform dan Identifikasi Escherichia coli pada Air Isi Ulang dari Depot di Kota Manado. J. Ilmiah Farmasi. 3(3): 325-334.

Besung INK, Tono PGK, Rompis ALT, Suarjana IGK. 2016. Prevalensi Pasteurella multocida pada Sapi Bali di Bali. Bul. Vet. Udayana. 8(2): 145-150. Destriyana LM, Swacita IBN, Besung INK. 2013. Pemberian Perasan Bahan Antimikroba Alami dan Lama Penyimpanan pada Suhu Kulkas $\left(5^{\circ}\right)$ terhadap Jumlah Bakteri Coliform pada
Daging Babi. Bul. Vet. Udayana. 5(2): 122-131.

Dewantari NRA, Besung INK, Sampurna IP. 2016. Pengaruh Pemberian Mineral terhadap Jumlah Bakteri Eschericia coli dan Coliform pada Sapi Bali di Dataran Tinggi dan Dataran Rendah. Bul. Vet. Udayana. 8(1): 71-78.

Kadarsih S. 2004. Performans Sapi Bali Berdasarkan Ketinggian Tempat Di Daerah Transmigrasi Bengkulu: I Performa Pertumbuhan. J. Ilmu Pertanian Indon. 6(2): 50-56.

Koneman EW, Procop GW. 2006. Color Atlas and Tetbook of Diagnostic Microbiology $6^{\text {th }}$ ed. J.B. Lippincott Company. Philadelphia.

Ray B. 2001. Fundamental Food Microbiology. $2^{\text {nd }}$ ed. CRC Press. New York.

Riko YA, Rosidah, Herawati T. 2012. Intensitas dan Prevalensi Ektoparasit Pada Ikan Bandeng (Chanos chanos) Dalam Karamba Jaring Apung (KJA) di Waduk Cirata Kabupaten Cianjur Jawa Barat. J. Perikanan dan Kelautan. 3(4): 231-241.

Suarjana IGK. 2009. Kualitas Air Minum Ternak Ayam Petelur di Desa Piling Kecamatan Penebel Kabupaten Tabanan di Tinjau dari Jumlah Bakteri Coliform. Bul. Vet. Udayana. 1(2): 5560.

Sikarwar AS. 2011. International Journal of Chemical Engineering and Applications. Armed. Force. Med. College. 2(2): 131-135. 